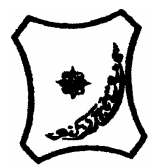

Bayero Journal of Pure and Applied Sciences, 6(2): 53 - 56

Received: April 2013

Accepted: December 2013

ISSN 2006 - 6996

\title{
ALLELOPATHIC EFFECT OF JATROPHA CURCAS(LIN) LEACHATE ON GERMINATION AND EARLY SEEDLING GROWTH OF FIVE (5) AGRICULTURAL CROPS IN KANO, NIGERIA
}

\author{
${ }^{1 *}$ Hassan, A., Mukhtar, F. B. and ${ }^{\mathbf{1}}$ Mohammed, I. M. \\ ${ }^{1}$ Department of Biological Sciences, Faculty of Science, UsmanDanfodiyo University, Sokoto. \\ Department of plant science, Faculty of Science, Bayero University Kano. \\ *Correspondence author
}

\begin{abstract}
Allelopathy refers to the chemical inhibition of one species by another. Decline in crop yields in cropping and agroforestry system in recent years has been attributed to allelopathy effects.Laboratory studies were conducted at Research Centre for Tissue Cu/ture, Kazaure, Jigawa state (Longitude08 ${ }^{\circ} 41^{\prime} \mathrm{N}$ and Latitude12 ${ }^{\circ} 65^{\prime} \mathrm{E}$ ). The aim of this study is to investigate the allelopathic potentials of aqueous leaf extract of Jatropha curcason seed germination and early seedling growth of five (5) crops. J. curcas aqueous leaf extract was prepared by $100 \mathrm{~g}, 50 \mathrm{~g}, 20 \mathrm{~g}$ powder dissolved in $500 \mathrm{ml}$ double distilled water and were tested for their allelopathic effect on some growth parameters of maize, millet, guinea corn, cowpea and ground nut. The effect of the different concentrations was compared with that of distilled water (control). Healthy seeds were sought and surface sterilized with $1 \%$ sodium hypochloride for 20 minutes. Laboratory study was conducted using sterilized petri dishes with double layer of Whatman filter paper at averagely $27^{\circ} \mathrm{C}$ and $70 \%$ humidity. An interval of 24, 48, 76 and 92 hours were recorded on germination studies while radicle and shoot lengths at 92nhours respectively. Decreased in germination percentage, shoot and radicle lengths of the crops studied were observed to be concentration dependent.All the concentration of the different extracts had inhibitory effect on the germination of all the crops compared to control. Phytochemical screening of the J. curcas leaf extract was also determined. Keywords: Allelopathy, Jatropha, Germination, Phytochemicals, Extract.
\end{abstract}

\section{INTRODUCTION}

Allelopathy is an interference mechanism in which live or dead plant material release chemical substances which inhibit or stimulate the associated plant growth (May and Ash, 1990). Allelopathy is all direct positive or negative effect of a plant on another or on microorganism by the liberation of biochemical (allelochemicals) into the environment (Elroy, 1984). Allelopathic chemicals can be present in any part of the plant. They can be found in the leaves, flower, roots, fruits or stems. They can also be found in the surrounding soil. These toxins affect target species in many different ways. Allelopathy also plays an important role in suppressing the growth of weed plants (Florentine and Fox, 2003).

Jatrophacurcas is a perennial poisonous shrub belonging to the family Euphorbeaceae. The plant originates from Central America to tropical and subtropical countries and mainly grown in Asia and Africa. Common names includes Barbados nut, purge nut, physics nut, black vomit nut, Curcas bean, the Hausa people of northern Nigeria called it 'Bini-dazugu'. Recently, Cheema and Ali (2003) have advocated commercial utilization of sorghum water extract for weeds management in wheat. Khan et al., (2004) reported that Prosopis, Eucalyptus and Acacia retarded the growth and development of several weeds.The failure of most crops in an agroforestry system has been attributed to allelopathic effect of the tree species. This phenomenon is as a result of phytochemical exuded by trees. These chemicals are largely classified as secondary metabolites (such as alkaloids, isoprenoids, phenolics, flavonoids, terpanoids\&gluconolatese.t.c (Naziret al., 2007). Combining trees with annual or perennial crops is a common practice among the local farmers. In many tree species leaf leachates had been reported to have varying degrees of inhibitory and stimulating effects on germination percentage. It has been argued that detailed study of allelopathy can reduce reliance on herbicides.

\section{MATERIALS AND METHODS}

Study area

Laboratory studies were conducted at Research Centre for Tissue Culture, Kazaure, Jigawa State on Longitude $08^{\circ} 41^{\prime} \mathrm{N}$ and Latitude $12^{\circ} 65^{\prime} \mathrm{E}$.

Preparation of the aqueous leaf extract

Fresh and manure leaf samples of J. curcas were collected randomly at vegetative stage in early 2010 from Old-site, Bayero University Kano. The leaves were shade dried and grounded using mortar and pestle then passed through $2 \mathrm{~mm}$ mesh sieve. Different amounts; $100 \mathrm{~g} / 500 \mathrm{ml}$, $50 \mathrm{~g} / 500 \mathrm{ml}$, $20 \mathrm{~g} / 500 \mathrm{ml}$ and $0 \mathrm{~g} / 500 \mathrm{ml}$ (control) of the ground materials were dissolved in sterilized distilled water in a $1000 \mathrm{ml}$ conical flask. These gave the percentage leaf extract in $100 \mathrm{ml}$ of water $20 \%, 10 \%, 4 \%$ and $0 \%$ (control). 
The mixture was then shaken intermittently and allowed to stand for 24 hours at room temperature. Thereafter the suspensions were filtered using layers of muslin cloth and then passed through No. 1 Whatman filter paper (Knox et al., 2010).

\section{Collection and sterilization of seeds}

Five (5) agricultural crops seeds were obtained from Kano Agricultural and Rural Development Authority (KNARDA). They includes Zeamay (ACR- 97; maize), Panicummiliaceum (Millet), Sorghum sudanense (SAMSORG 14 - KSV8; sorghum), Vignaunguiculata (277- 2; cowpea) and Arachis hypogea (SAMNUT- 23; ground nut). The grains were surface sterilized with $20 \%$ sodium hypochlorite for 15 minutes then rinsed severally with distilled water to remove the excess of the chemical. The seeds were presoaked in distilled water for two (2) hours and then soaked in different concentration of the aqueous leaf extracts for three (3) hours (Sazadaet al., 2009). Ten (10) seeds of each crop were germinated inside germination chamber on double layer of No. 1 Whatman filter paper in petri dishes with the different leachate concentrations and laid in Completely Randomized Design (CRD) with three replications. The petri dishes were clearly labeled. Germination and early seedling experiment was terminated after 5 days. Data was recorded on rate of germination at 24, 48,72 and 96 hours intervals while shoot and root lengths were measured using thread and metre rule at the final stage of the experiment.

\section{Phytochemical screening}

About $30 \mathrm{~g}$ of the powdered leaves were placed in a round bottom flask containing $200 \mathrm{~cm}^{3}$ of methanol and mixed. The round bottom flask was placed in a flask shaker and agitated for four (4) hours and left to stand overnight. The extract was then filtered and the filtered extracts were subjected to phytochemical tests for the identification of the bioactive components(Bukar and Mudi, 2011; Malviyaet al. 2011; Sofowora, 1993; Kumar et al., 2009).

\section{Statistical analysis}

Statistical analysis was performed employing one way analysis of variance (ANOVA) test using Microsoft Excel Window 2007. To detect the significance differences between means, least significant test was used at $5 \%$. All values are expressed as mean \pm standard deviation.

\section{RESULTS AND DISCUSSION}

The results in Table 1 showed the allelopathic effect of J.curcas aqueous leaf extract on millet, maize, guinea corn, cowpea and ground nut. Maximum germination percentage of the seeds were observed in all the control treatments with $100 \%$ germination attained within 76 hours after sowing in millet and maize, 48 hours in guinea corn and cowpea and 92 hours in ground nut. It was observed that the rate of germination decreased with increase in concentration of the leaf extract. However at 92 hours in the highest concentration (20\%) percentage germination decreased from $100 \%$ to $90 \%, 80 \%, 93.3 \%$ and $40 \%$ in millet, maize, guinea corn and ground nut respectively. High germination reduction was recorded at $20 \%$ concentration in maize and millet while highest inhibitory effect was obtained in ground nut where germination did not occur at 24 hours in all the treatments and only $10 \%$ and $23.3 \%$ were recorded at 48 and 76 hours.

Highest shoot length was obtained in the control treatments while the lowest shoot length was recorded in the highest concentration $(20 \%)$ with the exception of guinea corn where the minimum shoot length $4.5 \mathrm{~cm}$ was obtained in the $10 \%$ concentration. However the differences in the shoot lengths were not significantly different $(p<0.05)$ in all the crops treated with J.curcas extract. Root length was significantly $(p<0.05)$ reduced in millet seeds by all concentrations of the extract. The highest root length $(11.5 \mathrm{~cm})$ was observed in the control of millet and this decreased with increase in the concentration of the treatments to $6.5 \mathrm{~cm}$ in $20 \%$ treatment (Table 2). Phytochemical screening of leaf extracts of J.curcas indicate the presence of carbohydrate, tannin, flavonoid, glycoside, resin, saponin, steroids and fatty acids while Anthraquinones and alkaloid were not observed (Table 3).

Allelopathy is considered as both harmful and beneficial interaction between the plants. The result obtained from laboratory study showed that the leaf extract of J. curcas exhibited varying degree of allelopathy by inhibiting the germination and growth of the tested crops. In the laboratory, maximum percentage seed germination was shown in the control treatments where no extract was used whereas the lowest seed germination was obtained in the highest concentration (20\%). All the concentration of the different extracts had inhibitory effect on the germination of all the crops compared to control. These observations are consistent with findings on related plant species. Alam and Islam (2002) reported that plant produce chemicals which interfere with other plants and affect seed germination and seedling growth. Jadhar and Gayanar (1992) reported that percentage of germination, plumule and radicle length of rice and cowpea were decreased with increasing concentration of Acacia auriculiformis leaf leachate. Bhardwaj (1992) reported that leachates from $E$. globulus leaves significantly reduced maize germination but were ineffective on wheat germination. It was also observed (from the study) that the allelopathic potential of the J.curcas leaf extract is more pronounced in the germination study.Root length was strongly inhibited by the aqueous leaf extract of Jatropha in all the tested crops. A similar reduction of shoot length was also observed. It was also noticed that the decrease in root and shoot lengths seemed to increase with increase in concentrations of the extract. 
Table 1: The effect of different concentrations $(\mathrm{g} / \mathrm{ml})$ of Jatropha curcas aqueous leaf extract on germination percentage of millet, maize, guinea corn, cowpea and ground nut.

\begin{tabular}{|c|c|c|c|c|c|}
\hline $\begin{array}{c}\text { Crop type } \\
\text { and } \\
\text { Time (hr) }\end{array}$ & \multicolumn{4}{|c|}{ Concentration of $J$. curcas leaf Extracts } & \multirow{2}{*}{ LSD $5 \%$} \\
\hline Millet & Control & $20 \mathrm{~g} / 500 \mathrm{ml}$ & $50 \mathrm{~g} / 500 \mathrm{ml}$ & $100 \mathrm{~g} / 500 \mathrm{ml}$ & \\
\hline 24 & $40.0 \pm 6.15$ & $23.3 \pm 3.21$ & $23.3 \pm 3.21$ & $10.0 \pm 0.0$ & 16.30 \\
\hline 48 & $80.0 \pm 7.36$ & $56.6 \pm 5.10$ & $40.0 \pm 4.64$ & $30.0 \pm 4.64$ & 25.49 \\
\hline 76 & $100.0 \pm 0.0$ & $90.0 \pm 4.64$ & $70.0 \pm 4.64$ & $60.0 \pm 4.64$ & 16.3 \\
\hline 92 & $100.0 \pm 0.0$ & $100.0 \pm 0.0$ & $100.0 \pm 0.0$ & $90.0 \pm 4.64$ & NS \\
\hline \multicolumn{6}{|l|}{ Maize } \\
\hline 24 & $53.3 \pm 3.21$ & $30.0 \pm 4.64$ & $20.0 \pm 0.0$ & $10.0 \pm 4.64$ & 14.37 \\
\hline 48 & $90.0 \pm 0.0$ & $70.0 \pm 4.64$ & $70.0 \pm 4.64$ & $60.0 \pm 4.64$ & 16.30 \\
\hline 76 & $100.0 \pm 0.0$ & $100.0 \pm 0.0$ & $90.0 \pm 4.64$ & $80.0 \pm 4.64$ & 13.30 \\
\hline 92 & $100.0 \pm 0.0$ & $100.0 \pm 0.0$ & $96.6 \pm 3.21$ & $80.0 \pm 4.64$ & 10.87 \\
\hline \multicolumn{6}{|c|}{ Guinea corn } \\
\hline 24 & $60.0 \pm 4.64$ & $30.0 \pm 0.0$ & $30.0 \pm 4.64$ & $20.0 \pm 4.64$ & 16.30 \\
\hline 48 & $100.0 \pm 0.0$ & $90.0 \pm 0.0$ & $76.6 \pm 6.15$ & $70.0 \pm 4.64$ & 17.18 \\
\hline 76 & $100.0 \pm 0.0$ & $100.0 \pm 0.0$ & $80.0 \pm 7.36$ & $80.0 \pm 4.64$ & NS \\
\hline 92 & $100.0 \pm 0.0$ & $100.0 \pm 0.0$ & $93.3 \pm 3.21$ & $93.3 \pm 3.21$ & NS \\
\hline \multicolumn{6}{|l|}{ Cowpea } \\
\hline 24 & $70.0 \pm 7.31$ & $70.0 \pm 4.64$ & $60.0 \pm 0.0$ & $50.0 \pm 7.31$ & NS \\
\hline 48 & $100.0 \pm 0.0$ & $100.0 \pm 0.0$ & $100.0 \pm 0.0$ & $100.0 \pm 0.0$ & NS \\
\hline 76 & $100.0 \pm 0.0$ & $100.0 \pm 0.0$ & $100.0 \pm 0.0$ & $100.0 \pm 0.0$ & NS \\
\hline 92 & $100.0 \pm 0.0$ & $100.0 \pm 0.0$ & $100.0 \pm 0.0$ & $100.0 \pm 0.0$ & NS \\
\hline \multicolumn{6}{|c|}{ Ground nut } \\
\hline 24 & $30.0 \pm 4.64$ & 0.0 & 0.0 & 0.0 & 9.41 \\
\hline 48 & $73.3 \pm 6.15$ & $23.3 \pm 3.21$ & $20.0 \pm 4.64$ & $10.0 \pm 4.64$ & 20.3 \\
\hline 76 & $90.0 \pm 4.64$ & $50.0 \pm 4.64$ & $30.0 \pm 4.64$ & $23.3 \pm 3.21$ & 17.18 \\
\hline 92 & $100.0 \pm 0.0$ & $70.0 \pm 4.64$ & $50.0 \pm 4.64$ & $40.0 \pm 4.64$ & 16.30 \\
\hline
\end{tabular}

Values are expressed as Mean \pm standard deviation. NS = not significant, LSD $=$ Least significant difference.

Table 2: The effect of different concentrations $(\mathrm{g} / \mathrm{ml})$ of Jatropha curcas leaf extracts on shoot and root lengths $(\mathrm{cm})$ of millet, maize, guinea corn, cowpea and ground nut seedlings.

\begin{tabular}{|c|c|c|c|c|c|}
\hline Crop type & & Concentrat & of leaf extrac & & \\
\hline Shoot length & Control & $20 \mathrm{~g} / 500 \mathrm{ml}$ & $50 \mathrm{~g} / 500 \mathrm{ml}$ & $100 \mathrm{~g} / 500 \mathrm{ml}$ & LSD 5\% \\
\hline Millet & $6.0 \pm 1.50$ & $5.8 \pm 1.21$ & $5.6 \pm 0.45$ & $5.6 \pm 0.45$ & NS \\
\hline Maize & $3.4 \pm 0.96$ & $2.9 \pm 0.75$ & $3.7 \pm 0.91$ & $2.9 \pm 0.75$ & NS \\
\hline Guinea corn & $6.7 \pm 0.80$ & $5.2 \pm 0.75$ & $4.5 \pm 1.87$ & $6.4 \pm 0.91$ & NS \\
\hline Cowpea & $4.2 \pm 1.20$ & $3.5 \pm 1.10$ & $3.8 \pm 1.81$ & $3.3 \pm 1.56$ & NS \\
\hline $\begin{array}{l}\text { Ground nut } \\
\text { Root length }\end{array}$ & 0.0 & 0.0 & 0.0 & 0.0 & \\
\hline Millet & $11.5 \pm 2.27$ & $9.6 \pm 2.16$ & $7.1 \pm 1.05$ & $6.5 \pm 1.05$ & 3.55 \\
\hline Maize & $9.5 \pm 1.70$ & $7.8 \pm 2.02$ & $7.8 \pm 1.20$ & $7.2 \pm 3.30$ & NS \\
\hline Guinea corn & $10.3 \pm 1.13$ & $8.5 \pm 1.30$ & $7.8 \pm 1.53$ & $7.8 \pm 2.56$ & NS \\
\hline Cowpea & $4.6 \pm 1.51$ & $5.8 \pm 2.50$ & $6.2 \pm 1.50$ & $3.6 \pm 1.68$ & NS \\
\hline Ground nut & $1.8 \pm 1.37$ & $1.83 \pm 0.73$ & $1.8 \pm 0.60$ & $2.1 \pm 1.08$ & NS \\
\hline
\end{tabular}

Values are expressed asMean \pm standard deviation. NS = not significant, LSD= Least significant difference.

Table 3: Phytochemical screening of $J$. curcas leaf extract using water and methanol as extract solvent.

\begin{tabular}{clcc}
\hline Test & A & B \\
\hline 1. Carbohydrate & + & + \\
2. Alkaloid & - & - \\
3. Tannin & + & + \\
4. Flavonoids & + & + \\
5. Glycosides & + & + \\
6. Resins & + & + \\
7. Steroids & + & + \\
8. Saponin & + & + \\
9. Anthraquinone & - & - \\
10. Fatty acids & + & +
\end{tabular}

Key: $A=$ water solvent, $B=$ methanol solvent, $(+)$ present, $(-)$ absent. 


\section{CONCLUSION}

Conclusively, from the results obtained it showed that the aqueous leaf extract of $J$. curcas at all the concentrations inhibited germination, root and shoot lengths of cowpea, ground nut, maize, millet and guinea corn. Aqueous leaf extract of $J$. curcas can be a good candidate for future field experiment and use as natural herbicide.

\section{REFERENCES}

Alam, S.M and E. U. Islam.(2002). Effect of aqueous extract of leaf, stem, root of neetle leaf goose foot and $\mathrm{NaCl}$ on germination and seedling growth of rice. Pakistan Journal of Science and Tech. 1 (2): 47- 50.

Bukar, A and Mudi S. Y. (2011) Preliminary Phytochemical screening and antimicrobial activity of Anogiessus leiocarpus stem bark extracts against some food-borne pathogens, Biological and environmental sciences Journal for the tropics, 8(1): 51- 55.

Cheema and Ali M. A. (2003).Allelopathic effect of Sorghum Water Extract on Germination and seedling growth of Trianthemaportula castrum. International Journal of Agriculture and Biology, 4: 383-384.

Elroy, L. (1984). Allelopathy. (Second Edition ed.). Academic Press. United kingdom, pp. 422.

Florentine, S. K and Fox, J. E. D. (2003). Allelopathic effects of Eucalyptus victrix L. on Eucalyptus species and grasses. Allelopathy Journal, 11: $77-83$.

Jadhar, B, B and Gayanar, D. G (1992) Allelopathic effects of Acacia auriculiformis on germination of rice and cowpea, India, Journal of Plant Physiol., 1: 86- 89.

Khan, M.A.,Marwat. K. B and Hassan, Z. (2004). Allelopathic potential of some multipurpose trees species (MPTS) on the wheat and some of its associate's weeds. International Journal of Biology And Biotechnology, 1(3): 275278.

Knox. J, Disha. J and Poul, M. S (2010) Evaluation of allelopathic potentials of selected plants on

\section{Recommendations}

i. Farmers should avoid intercropping, demarcating or fencing their farm land withJ.curcasas this may affect their farm produce.

ii. Further studies are suggested to investigate on molecular, genetic and physiological mechanisms of the observed allelopathy.

Parthenium hysterophorus. Egyptina Journal of biology, 12: $57-64$.

Kumar.A, R. Lievarasani, T. Jayachandra, $M$. Decavaman, P. Aravindhan, N. Padmanabhan and Krishnan, M.R.V. (2009) "Phytochemicals investigation on a tropical plant, syzygium cumini from Kattuppalayam", Erode District, Tamil Nadu, South India.Pakistan Journal of Nutrition. 8(1):83- 85.

Malviya. S, Rawat. S, Verma. M and Kharia, A.(2011) Preliminary Phytochemical Investigations of Acacia nilotica Linn, Current Pharma Research, 1(2), 91-100.

May, F.E. and Ash, J. E. (1990). An assessment of the allelopathic potential of Eucalyptus. Australia Journal of Botany, 38: 245-254.

Nazir, T., Uniyal.A.K and Todaria, N. P (2007) Allelopathic behavior of three medicinal plant species on traditional agriculture crops of Garhwal Himalaya, India. Agroforestry System, 69: 183-187.

Sazada.S.,Shipla. B,Khan. S. S and Kumar. M. M (2009) Allelopathic effect of different concentration of water extract of Prosopsisjuliflora leaf extract on seed germination and radicle length of wheat (Triticumaestivum var-Lok-1), AmericanEurasian. Journal, 4(2): 81-84.

Sofowora, 0.0 (1993) Medicinal plants and traditional medicine in Africa. Spectrum books limited, Ibadan, Nigeria. p104.

Thakur, V.C and Bhardwaj, S. D (1992) Allelopathic effect of tree leaf extract on germination of wheat and maize. Seed Res. 20: 153- 154. 